\title{
The level of blood plasma mitochondrial DNA upon acute myocardium damage in experiment
}

\author{
N. P. Sudakovi, , T. P. Popkova ${ }^{3}$, M. A. Novikova ${ }^{1}$, A. I. Katyshev ${ }^{2}$, S. B. Nikiforov', \\ B. G. Pushkarev ${ }^{1}$, O. A. Goldberg' ${ }^{1}$ I. B. Klimenkov ${ }^{4,6}$, S. A. Lepekhova ${ }^{1}$, \\ S. D. Ezhikeeva ${ }^{3}$, M. N. Ten ${ }^{3}$, V. G. Osipov ${ }^{5}$, Yu. M. Konstantinov ${ }^{2,6}$
}

\author{
${ }^{1}$ Scientific Center for Reconstructive and Restorative Surgery, Siberian Branch, Russian Academy of Medical Sciences \\ 1 , Bortsov Revolyutsii Str., Irkutsk, Russian Federation, 664003 \\ ${ }^{2}$ Siberian Institute of Plant Physiology and Biochemistry, Siberian Branch of the Russian Academy of Sciences \\ 132, Lermontova Str., Irkutsk, Russian Federation, 664033 \\ ${ }^{3}$ Regional Clinical Hospital \\ 100, m-n Yubileinyi, Irkutsk, Russian Federation, 66409 \\ ${ }^{4}$ Limnological Institute, Siberian Branch of the Russian Academy of Sciences \\ 3, Ulan-Batorskaya Str., Irkutsk, Russian Federation, 665033 \\ ${ }^{5}$ Territorial Center of Catastrophe Medicine \\ 100 k3, m-n Yubileinyi, Irkutsk, Russian Federation, 664049 \\ ${ }^{6}$ Irkutsk State University \\ 1, Karl Marks Str., Irkutsk, Russian Federation, 664003 \\ npsudakov@rambler.ru; yukon@sifibr.irk.ru
}

\begin{abstract}
The aim of the present investigation is to study the level of plasma mtDNA as a potential marker of cardiomyocyte damage in 2 and $4 \mathrm{~h}$ after subcutaneous injection of adrenaline and during the formed morphological alterations of the myocardium ( 3 days). Methods. Real time PCR. Male Wistar rats were used as the experimental animals. Results. It was shown that during the increase in the activity of cytolysis biomarkers, at the first hours after adrenaline injection, no reliable increase is observed in the level of free circulating blood mtDNA. A tendency of 2.5-fold increase in this parameter was established at the third day after adrenaline injection during the development of acute inflammatory process in the myocardium. On the whole, further researches are needed on the dynamics of mtDNA level upon acute damage of the myocardium in experimental and clinical investigations for unbiased estimation of the prospects of using the parameter in laboratory diagnostics.
\end{abstract}

Keywords: mitochondrial DNA, cardiovascular diseases, adrenaline myocarditis, cytolysis biomarkers.

Introduction. Cardiovascular diseases are currently one of the major causes of mortality incidence increase in developed countries. The efficiency of prevention and therapy of acute ischemic damage of the myocardium is determined by the potential of diagnostic screening and monitoring techniques [1]. The utilization of the currently known range of cytolysis biomarkers does not always allow definite determination of patient state and cardiac infarction cure option selection [2]. Therefore,

(c) Institute of Molecular Biology and Genetics, NAS of Ukraine, 2012 the search for novel cardiomyocyte damage biomarkers and their pathological basis is an urgent task [1]. A promising nonspecific marker of cytological processes is the level of free circulating mitochondrial DNA (mtDNA) of blood plasma. The level of free and cellular blood mtDNA was established to be a criterion for disease complication and mortality prognosis in different pathological processes (tumors, bacterial meningitis) [3-5]. Currently, the dynamics of this parameter remains unexplored for cardiovascular diseases. Despite the lack of tissue specificity, the possibility to utilize this parame- 

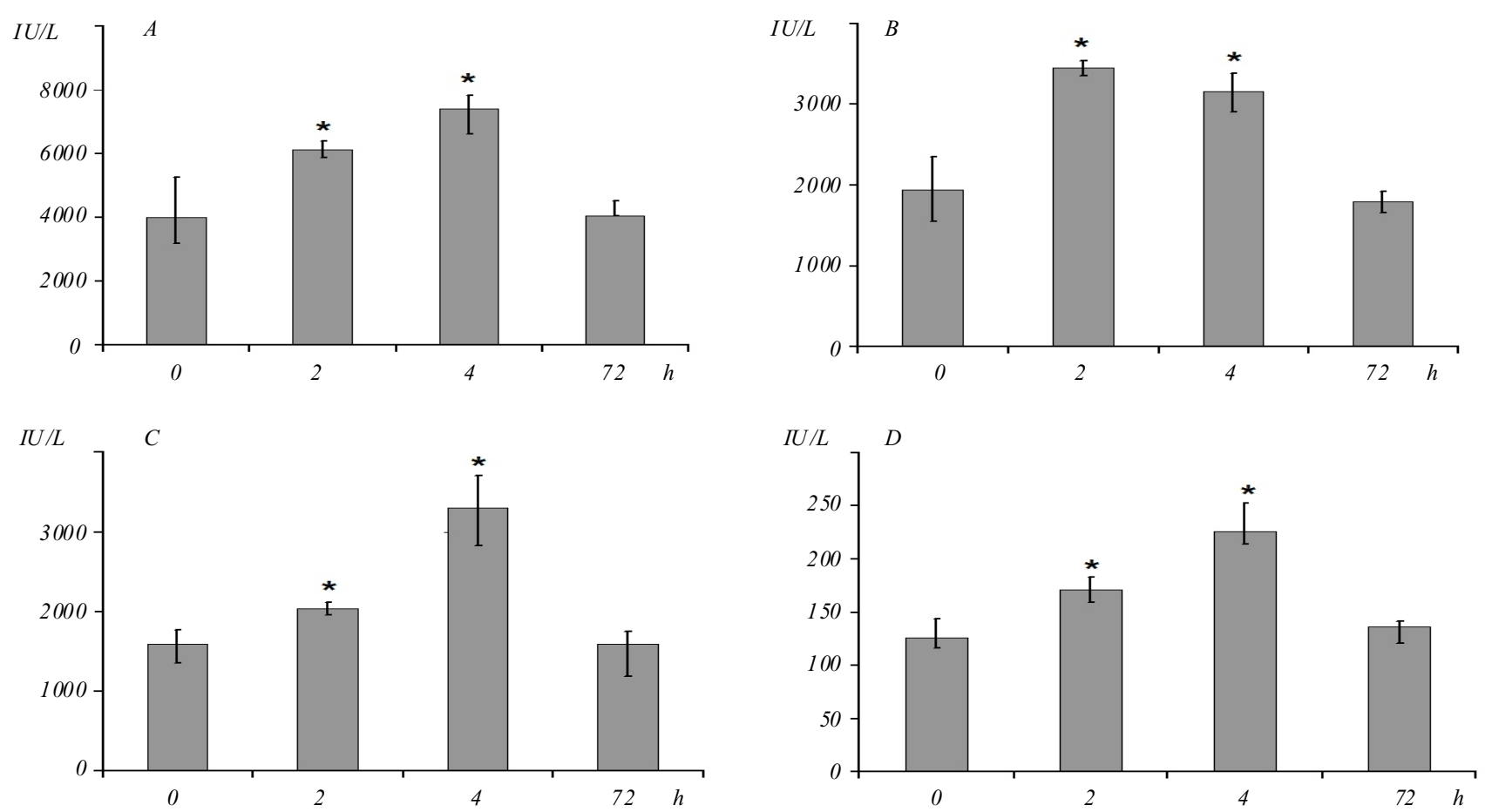

Fig. 1. Activity of cytolysis biomarker enzymes during adrenaline myocarditis: $A$ - creatine kinase; $B$ - creatine phosphokinase-MB; $C$ - lactate dehydrogenase; $D$ - aspartate transaminase; ${ }^{*} \mathrm{p} \leq 0.05$ versus control group

ter in addition to the cardiospecific cytolysis biomarkers for acute and chronic cardiovascular disease diagnostics and prognosis is of scientific and practical interest. Therefore, the aim of the present research is to investigate the level of plasma mtDNA as a potential marker of cardiomyocyte damage during the first hours of adrenaline myocarditis modeling and upon developed morphological alterations in the myocardium.

Materials and methods. Male Wistar rats were used as the experimental animals that were divided into two groups: 1) control ( $n=6$, subcutaneous injection of the physiological solution); 2) experimental myocarditis ( $n=18$, subcutaneous injection of $0.2 \mathrm{mg}$ of adrenaline hydrochloride per $100 \mathrm{~g}$ of animal body weight). The animals were sacrificed in $2 \mathrm{~h}(n=6), 4 \mathrm{~h}(n=6)$, and 3 days $(n=6)$; blood was collected and autopsy was performed [6].

Blood of the experimental animals stabilized with nitrate citrate was used to obtain blood plasma free of thrombocytes [3]. DNA was extracted from blood using the DNA-probe reagent kit («DNA-technology», Russia). Quantitative analysis of mtDNA was performed using the real time PCR approach with the iCycler IQ4 amplifier («Bio-Rad», USA) and DTlite («DNA-technolo- gy»). The 16S RNA fragment (direct primer: 5'-TGCA GAAGCTATTAATGGTTCG-3', reverse primer: 5'-T TGGCTCTGCCACCCTAATA-3') was amplified [4]. A reaction mixture containing SYBR Green (MaximaTM SYBR Green/ROX qPCR Master Mix - «Fermentas», Lithuania) was used for real time PCR. All the manipulations with the experimental animals were conducted according to the regulations for experimental research (Ministry of Health, Soviet Union, Order of August 12, 1977, N 755). The results were analyzed using non-parametric statistics and median, and quartiles were calculated; intergroup differences were assessed with the Mann-Whitney and Kraskel-Wallace criteria.

Results and discussion. In $2 \mathrm{~h}$ after adrenaline injection, statistically reliable increase $(p \leq 0.05)$ was recorded in the activity of cytolysis biomarker enzymes: creatine kinase $(120 \%)$, creatine phosphokinase-MB $(150 \%)$, lactate dehydrogenase $(130 \%)$, and aspartate transaminase $(140 \%)$ in the blood of the experimental animals. The values of creatine kinase, lactate dehydrogenase, and aspartate transaminase activity continued to increase reliably for $4 \mathrm{~h}$ (Fig. 1). The data obtained definitely evidence to the occurrence of cardiomyocyte damage after adrenaline injection at these points of the 


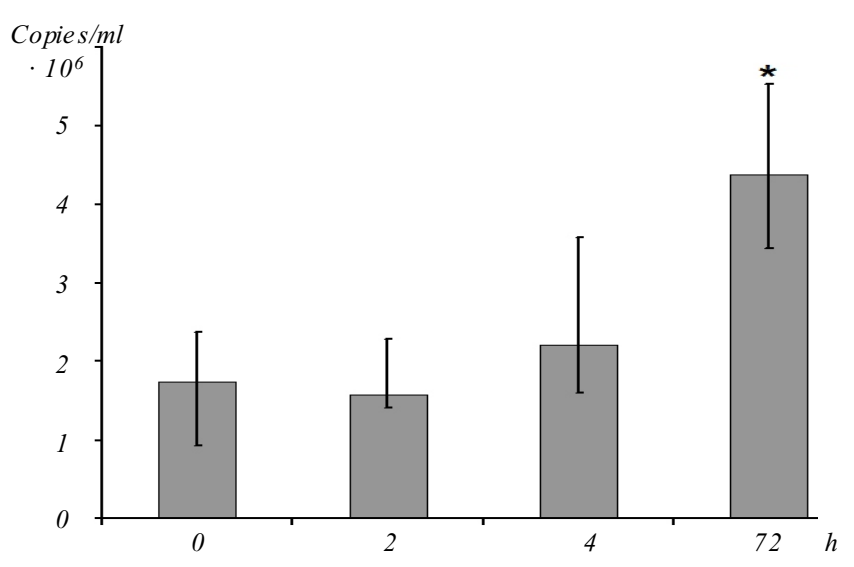

Fig. 2. Alterations in the level of free circulating blood mtDNA during adrenaline myocarditis; ${ }^{*} \mathrm{p}=0.16$ versus control group

experiment. The level of free circulating plasma mtDNA had no statistically reliable difference from the control group in 2 and $4 \mathrm{~h}$ after adrenaline injection (Fig. 2).

In 3 days, the myocardium of the animals with adrenaline injections was characterized by marked myocarditis symptoms: multiple lysis focuses of muscle fibers infiltrated with macrophages were observed on the preparations stained with the hematoxylin and eosin (Fig. 3 ,). The focuses of inflammation were found both in the central part of the myocardium and in direct contact with the endocardium and pericardium. Myocardium infiltration with macrophages was focal in some cases. In the experimental group, the activity of cytolysis biomarkers decreased and virtually had no difference from the values of the control group at this period. Nevertheless, it was registered 2.5 fold increase in free

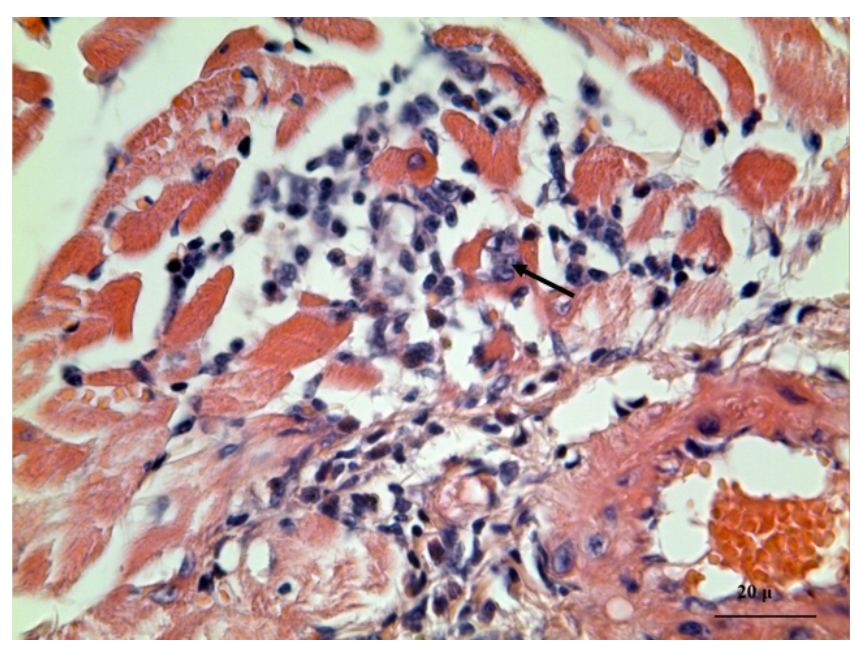

Fig. 3. Development of morphological alterations in the myocardium at the third day after adrenaline injection. The lysis focuses of myocardium fibers infiltrated with macrophages (arrow) plasma mtDNA level in the experimental animals as compared to the control subjects under 3 days of experimental myocarditis modeling $(\mathrm{p}=0.16)$. It is likely that detailed analysis of mtDNA level dynamics is needed between 4 and $72 \mathrm{~h}$ of myocarditis modeling as well as at later periods after adrenaline injection for unbiased interpretation of the obtained data.

Thus, during the first hours after adrenaline injection, no reliable increase occurs in the level of free circulating mtDNA, due to its potential efflux from the damaged tissues. A tendency was observed of increase in this parameter at the third day after injection during acute inflammatory process development in the myocardium.

Conclusion. The data obtained evidence to the fact that despite strong efflux of cytolysis biomarkers from the damaged myocardium in 2 and $4 \mathrm{~h}$ after subcutaneous adrenaline injection, no increase occurs in the level of free circulating blood mtDNA of the experimental animals. This fact excludes the possibility to employ this parameter for cell damage monitoring at these periods of adrenaline myocarditis. Relatively insignificant increase in this parameter is observed at the third day after adrenaline injection upon a decrease in cytolysis marker activity and the development of acute inflammation process in the myocardium. Possible explanation for the increase in mtDNA level observed at the third day of the experiment is mtDNA release from the polymorphonuclear phagocytes in the form of extracellular traps, when inflammation is activated in the damaged myocardium [7]. This possibility is of interest for the construction of techniques for inflammation process after acute ischemic myocardium damage and requires further investigations. It is undoubtedly that the characterized points of adrenaline myocarditis development are not sufficient for the objective representation of possible alterations in mtDNA level. One more probable cause of the obtained results can be the insufficiency of myocardium damage induced in this experiment that predetermines to perform ligation of coronary arteries.

All the above stated facts make it urgent to explore in detail the dynamics of this parameter during acute damage and inflammatory processes in the myocardium in experiment and clinics that will later favor the development of novel techniques for acute myocardium damage and diagnostics. 
Acknowledgements. This work was financially supported by the Presidium RAS Program «Fundamental Science for Medicine» (project FNM-16) and Russian Fund for Basic Research (09-04-01341, 12-04-01400).

Н. П. Судаков, Т. П. Попкова, М. А. Новікова, А. І. Катишев,

С. Б. Никифоров, Б. Г. Пушкарев, О. А. Гольдберг,

I. В. Клименков, С. А. Лепехова, С. Д. Сжикеєва, М. Н. Тен,

В. Г. Осипов, Ю. М. Константинов

Рівень мітохондріальної ДНК плазми крові за гострого пошкодження міокарда в експерименті

\section{Резюме}

Мета. Вивчити рівень мтДНК плазми крові як можливого маркера пошкоджень кардіоміочитиів через 2 і 4 год після підшкірної ін'єкиії адреналіну та на фоні сформованих морфологічних змін міокарда (3-тя доба). Методи. Полімеразна ланцюгова реакція у реальному часі. В експериментах використано самиів шурів лінії Вістар. Результати. Показано, щьо поряд із збільшенням активності біомаркерів циитолізу в перші години після введення адреналіну суттєвого підвищення рівня вільно ииркулюючої мтДНК крові не відбувається. Встановлено тендениію до 2,5-разового зростання даного показника на 3-тю добу після ін 'киї̈ адреналіну на фоні розвитку гострого запального процесу в міокарді. Висновки. У цілому для об 'єктивної очінки перспектив цього показника у лабораторній діагностиці інфаркта міокарда необхідно подальше вивчення динаміки рівня мтДНК при гострих ураженнях міокарда в експериментальних $і$ клінічних дослідженнях.

Ключові слова: мітохондріальна ДНК, сериево-судинні захворювання, адреналіновий міокардит, біомаркери цитолізу.

Н. П. Судаков, Т. П. Попкова, М. А. Новикова, А. И. Катышев, С. Б. Никифоров, Б. Г. Пушкарев, О. А. Гольдберг,

И. В. Клименков, С. А. Лепехова, С. Д. Ежикеева, М. Н. Тен, В. Г. Осипов, Ю. М. Константинов

Уровень митохондриальной ДНК плазмы крови при остром повреждении миокарда в эксперименте

Резюме

Цель. Изучить уровень мтдНК плазмы крови как возможного маркера повреждений кардиомиоцитов через 2 и 4 ч после подкожной инъекции адреналина и на фоне сформированных морфологических изменений миокарда (3-и сут). Методы. Полимеразная иепная реакция в реальном времени. В экспериментах использовали самцов крыс линии Вистар. Результаты. Показано, что наряду с увеличением активности биомаркеров циитолиза в первые часы после введения адреналина значимого повышения уровня свободно ичркулирующей мтДНК крови не происходит. Установлена тенденциия к 2,5-кратному возрастанию данного показателя на 3-и сут после инъекции адреналина на фоне развития острого воспалительного проиесса в миокарде. Выводы. В иелом для объективной оченки перспектив этого показателя в лабораторной диагностике инфаркта миокарда необходимо дальнейшее изучениеп динамики уровня мтдНК при острых повреждениях миокарда в экспериментальных и клинических исследованиях.

Ключевые слова: митохондриальная ДНК, сердечно-сосудистые заболевания, адреналиновый миокардит, биомаркеры изитолиза.

\section{REFERENCES}

1. Searle J., Danne O., Muller C., Mockel M. Biomarkers in acute coronary syndrome and percutaneous coronary intervention // Minerva Cardioangiol.-2011.-59, N 3.-P. 203-223.

2. Ricci F., De Caterina $R$. Isolated creatine kinase-MB rise with normal cardiac troponins: a strange occurrence with difficult interpretation // J. Cardiovasc. Med. (Hagerstown).-2011.-12, N 10.-P. 736-740.

3. Chiu R. W., Chan L. Y., Lam N. Y., Tsui N. B., NgE. K., Rainer T. $H$., Lo Y. M. Quantitative analysis of circulating mitochondrial DNA in plasma // Clin. Chem.-2003.-49, N 5.-P. 719-726.

4. Ellinger J., Muller S. C., Wernert N., von Ruecker A., Bastian P. $J$. Mitochondrial DNA in serum of patients with prostate cancer: a predictor of biochemical recurrence after prostatectomy // BJU Int.-2008.-102, N 5.-P. 628-632.

5. Zachariah R. R., Schmid S., Buerki N., Radpour R., Holzgreve $W$., Zhong $X$. Levels of circulating cell-free nuclear and mitochondrial DNA in benign and malignant ovarian tumors // Obstet. Gynecol.-2008.-112, N 4.-P. 843-850.

6. Nepomnyashchikh L. M. Alternative insufficiency of muscle cells of the heart upon metabolic and ischemic damage.-Moscow: RAMS publishing house, 1998.-111 p.

7. Yousefi S., Mihalache C., Kozlowski E., Schmid I., Simon H. U. Viable neutrophils release mitochondrial DNA to form neutrophil extracellular traps // Cell Death Differ.-2009.-16, N 11.P. 1438-1444. 